\title{
$\mathrm{V}$. 探鉱技術分科会（分類 7)
}

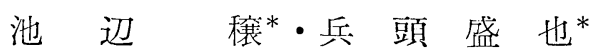

11 月 16 日（水）午後打よび 17 日（木）午前中の 2 日間，探鉱技術分科会は本会議場に打いて開かれた。 部会長は ECAFE 事務局の W. B. Metre 氏 (インド), リポーターはマレーシアの Schweighauser 博士が選ば れ, 日本代表団は議題の内容力ら地質と地球物理の専門 分野の代表が出席した。分類 7 の議題は ECAFE 地域 に特に関係のある探鉱技術と方法についてであり，(1)一 般および試掘に関係するもの, (2)微古生物学と花粉学に 関するもの，(3)物理探鉱技術とその解析法に関するも の，の 3 つの内容に分けて，順次討論された。

各国から提出された報文は 44 , そのうち 21 編は ECAFE 地域に抢ける各国の探鉱状沉についての報告お よび坑井地質の技術の絡介であり，6編は微古生物学的 および花粉学的研究に関するもので, 残りの 17 編が物 理探鉱の技術とその解析に関するものであった。

\section{1. 各国の探鉱技術一般}

一般的な探釷技術に関する紹介の報文は，他の分科会 または部会と重複しているものが多いため, 比較的スピ ーデーに議事が進行した。順㸝は $\mathrm{ABC}$ 国名順で, 例に よってアフガニスタンから始まった。

オーストラリアからは坑井地質調査に関連するコア・ カッティングの試料の記録方法（番号 118）やコア分析 方法（番号 121）の紹介があり，また海洋探鉱の現状と その方法（番号 120）について興味のある報告があった。 ビルマは最近種々の方法で 積極的に探鉱を進めてお り, 航空写真地質と重力探鉱が特に効果があって, 新油 田が発見された経過について説明があり, 地震探鉱につ いては，低速度層の存在のために反射記録の乏しい地区 が意外に多く, 余り効果が上がらないで困っていること が報告され（番号 136）, 同じなやみを有する中国（台 湾) やソ連などから活溌な質問や意見が出され, 稲作地 带に打ける研究の進んでいる日本に対して意見を求めら れたりした。

フランスからは ECAFE 地域に㧊いて実施した海底 における地質学的および地球化学的な調査についての報 文（番号 51）の紹介があった。日本からは，秋田県の脇
本沖において音響測深器によって海底岩盤の地形調査を 実施したところ, “背斜構造が非常にきれいに画かれた例 （番号 77）を紹介し，興味をもたれた。マレーシア打よ びオランダからは, 北西ボルネオ海域の海洋試掘と開発 についてくわしい報文が出された（番号 13，62）。海洋 掘さくの方法や遭遇している問題点は数多くあるが，そ れらについては分類 8 の部会で詳細に行なわれたので, 本分科会では簡単な紹介にとどまった。

ソ連からは，同国における石油地質学の業績（番号 26）と地球物理学的および地球化学的な方法の発展（番 号 29）について報告された。咥素の存在が炭化水素の 存在に対して否定の指示として用いられることや，特殊 なバクテリアの存否が地下の炭化水素の存否に関係して いるという結果を得た地域があること，などは各国の興 味を換起した。これらの方法はまだ研究域を出ないもの もあり，探鉱への応用については今後の開発にまたるば ならない。ソ連からはそのほかシベリア低地带における 探鈗の手順について紹介された（番号 133）。

\section{2. 微古生物学および花粉学}

イスラエル・日本・オーストラリアなどから報文が出 されていたが，これらの報文の多くは，対比特別分科会 で討論の材料にされたので，本分科会では $2 ， 3$ の報文 が紹介されただけであった。日本から提出された浅野・ 高柳の 浮遊性有孔虫の層位学的研究 (番号 69), 中世 古・岩本・高橋の放散虫による対比 (番号 70 ), 徳永の 花粉学の応用（番号 74）はいずれも各国代表から興味 をもたれ，特に最近採り上げられた花粉学については， もっとデータについての情報を求める質問があったが, 著者の出席がなかったので満足のいく回答ができなかっ たのは残念であった。

オーストラリアからは中生代の地層の細分のために花 粉を応用できることが報告された（番号 119）。

\section{3. 地球物理学的方法}

オーストラリアからは重力の概査に関する報告（番号 122，124）と地震挆鈗における Vibroseis 法**の使用に

\section{* 石油資源開発 $\mathrm{KK}$}

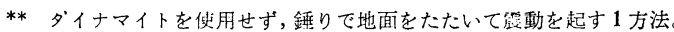


ついての報告（番号 123）があった。フランスからは重 力・磁力の結果の総合解釈 (番号 96), あるいは進んた 磁力探鉱法によって広籍囲地域の開発に対する物理挆鉱 法の応用 (番号 97), 精密な磁力調査すなわり $1 / 10$ ガン マのデジタル記録の応用（番号 95）などを述べた報文 が提出された。海上地震探鉱で, 極少量の火薬 (100 gr) を用いる方法の研究結果（番号 51）もフランスから発 表され注目された。従来の 1 回につき $15 \sim 50 \mathrm{~kg}$ の爆涾 を使用する方法では, 魚類に与える損害, バブル, 海底 と水面との間の多重反射のための記録の乱れなどの多く の欠点があるので, IFP の過去数年間の研究の結果, 発 震源として新しい万法を見出した。それは Flexoshooting という方法で，魚類に影響のない極めて少量の爆薬 を繰り返し爆破することにより，普通の反射法の発破に 匹敵するエネルギーを発するものであり，バブルの影響 む大幅に取り除かれる。爆破間隔は現在 30 秒に 1 回で あるが，15 秒に 1 回まで短縮できる見込みである。こ の機構は，穴のあいた中空の鋼鉄球の中心に爆薬を装填 する方法で，鋼鉄球は柔軟性のチューブによって爆破船 により海中を引張られていく。そのチューブは自動的に 爆薬を装填したり，爆破の操作を伝える。爆破後，鋼鉄 球はバブリングによる振動を小さくする減衰装置として
俉く。爆薬はかなりの深度で爆発させることができ， $100 \mathrm{gr}$ 以下の薬量で垫通の大薬量に匹敵する記録が得ら れた。度々の爆破にもかかわらず薬量の節約ができ，魚 類に刘しても安全であった。これは 1966 年には実用化 されるそうで, 魚類保護の問題のある海域では特に重要 な研究であり，大いに期待されるところである。

日本は物理探鉱法については 6 編の報文を用意した。 新潟平野の軟弱な表層の厚い地域における反射地震記録 の改善についての実験（番号 76）は, 稻作地帯の多い東 南アジア諸国にとって関心の深い問題であり, 特に注目 された。内容は多孔爆破および火薬の深部設置と重合法 による記録の改善である。日本の音波探査の紹介（番号 78), 地震模型実験による Baried Focus の研究 (番号 80) などの解析に関する問題も論ぜられ, ガスおよび石 油探鉱への電気探鉱法の有用性についての報告（番号 81）は，電気探鉱法の結果による基盤の形状が，他の方 法によるものと良く一致している例を示した。

探鉱技術に関する報告は，質量ともに日本のものがま さり, 各国代表から注目され, 興味をもたれたことは会 場の霝囲気から感ぜられた。これらの技術の紹介が，将

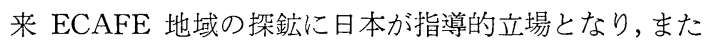
海外油田開発への道を開く足がかりとなるものと思う。

\title{
VI. 石油および天然ガスの開発と生産（分類 8)
}

\author{
藤 井 清 光 ${ }^{*}$ 松 本 英 二**
}

分類 8 については，39 編の報文が提出された。これ らは第 2 部会としてオーストラリア代表の TaylorRogers 氏が部会長となって 3 日間にわたって討議され た。報文は内容別に分類されて，まず部会長が報文の内 容を簡単に説明し，次に報文提出国に対して迫加説明を 要求した。次に各国代表は報文の内容について 質問し た。天然ガスの開発に関して，特にわが国に翼問された 事項は, 天然ガスの埋蔵量計算, 水溶性天然ガスの経済 性, 天然ガスの利用計画などであった。ソ連の生産技術 およびさく井技術に関しては質問が集中し，ソ連代表が これらについて詳しく説明したことは印象的であった。 わが国のさく井技術に関しては, 海洋掘さくの設備, 掘 進速度などが質問された（なお，ソ連代表は，シンポシ ウム終了後頸城に視察に行った)。

以下には提出された報文のうち，わが国の技術者に参

* 東大工学部資源開発工学科

** 耍国石油 K K
考になりそうなもののみに限定して，概略を説明する。 内容により, (1) ECAFE 地域の油・ガス田の開発経過, 掘さく方法, (3) 油層工学执よび生産技術に分類した。

\section{ECAFE 地域の油・ガス田の開発経過}

次の各国より探鉱および開発の経過が報告された[( ) 内は報文数]。アフガニスタン(2)・オーストラリア(3). 中国 (台湾) (1)・日本 (5)・ニュージーランド (1)・タ イ（1）。これらの報告はいずれも実際の開発経過を知る 上に非常に貴重なものである（以上は分類 5 と 8 に属す る)。

\section{2. 掘さく方法}

\section{1. アフガニスタンにおける掘さく（番号 43）}

アフガニスタン北部の Yatin Tagh と Khwaja Gogerdak 構造に掘さくが行なわれ, 大量のガスが発見さ れた。Yatin Taghにおいては 400〜 480 m の坑井 6 坑, 